\title{
Research Article \\ Probabilitas dan determinan pemanfaatan asuransi kesehatan di Indonesia (berdasarkan data IFLS tahun 2015)
}

The probability and determinants of the utilization of health insurance in Indonesia: analysis of 2015 IFLS data

Miftakhun Nafisah Yannis Putri ${ }^{1}$, Pujianto $^{2}$

\section{Dikirim:}

11 Januari 2019

Diterbitkan:

25 Februari 2019

\section{Abstract}

Background: Although JKN is expected to help the poor to access health facilities and to reduce the cost of out of pocket expenditure, the implementation of this program is known to remain spending out of pocket money or residents do not take advantage of the guarantees they obtain. Purpose: This study investigates the probability and the determinants of use of health insurance in Indonesia. Method: The Indonesian Family Life Survey (IFLS) 2015 data were used and analyzed by logistic regression/probit. Age, gender, marital status, family status, education, employment status, and area of residence were used as determinant variables. Results: The proportion of utilization of health insurance is $39.9 \%$. A total of $60.02 \%$ of health insurance owners do not use health insurance and issueout of pocket (OOP) fees. Age variables $(0.037)$, education $(0,000)$ and residential areas $(0,000)$ were significantly significant $(p$-value $<0.05)$ for the use of health insurance.

Keywords: health insurance utilization; age; education; residential area; probit

${ }^{1}$ Magister Study of Health Economics, Public Health Faculty, University of Indonesia

${ }^{2}$ Centre For Health Economics and Policy Study, University of Indonesia 


\section{PENDAHULUAN}

Semua penduduk Indonesia wajib menjadi peserta jaminan kesehatan yang dikelola oleh BPJS termasuk orang asing yang telah bekerja paling singkat enam bulan di Indonesia dan telah membayar iuran. Jaminan Kesehatan Nasional (JKN) adalah jaminan berupa perlindungan kesehatan agar peserta memperoleh manfaat pemeliharaan kesehatan \& perlindungan dlm memenuhi kebutuhan dasar kesehatan yg diberikan kepada setiap orang yg telah membayar iuran atau iurannya dibayar oleh Pemerintah Jaminan Kesehatan Nasional (JKN) merupakan bagian dari Sistem Jaminan Sosial Nasional (SJSN) yang diselenggarakan dengan menggunakan mekanisme asuransi kesehatan sosial yang bersifat wajib (mandatory) berdasarkan Undang-Undang Nomor 40 Tahun 2004 tentang SJSN dengan tujuan untuk memenuhi kebutuhan dasar kesehatan masyarakat yang layak yang diberikan kepada setiap orang yang telah membayar iuran atau iurannya dibayar oleh Pemerintah. BPJS Kesehatan adalah badan yang ditunjuk untuk menyelenggarakan $\mathrm{JKN}^{1-3}$.

Upaya mewujudkan jaminan kesehatan bagi seluruh penduduk atau jaminan kesehatan semesta sesuai amanat Undang-Undang Dasar 1945 dan Undang-Undang no. 40 tahun 2004 tentang Sistem Jaminan Sosial Nasional (SJSN), pemerintah meluncurkan program Jaminan Kesehatan Nasional (JKN) pada awal tahun 2014 dengan target bahwa kepesertaan semesta akan tercapai dalam jangka waktu lima tahun. Artinya, setiap individu wajib menjadi peserta dan terlindungi dalam program asuransi kesehatan sosial nasional ${ }^{4}$. Jaminan kesehatan semesta ini bertujuan untuk meningkatkan akses masyarakat pada pelayanan kesehatan yang komprehensif, bermutu dan merata bagi seluruh penduduk.

Adanya program JKN yang diselenggarakan Badan Penyelenggara Jaminan Sosial Kesehatan diharapkan membantu masyarakat yang selama ini tidak mampu mengakses layanan atau fasilitas kesehatan. Adanya JKN juga diharapkan mampu menekan biaya OOP dari pengeluaran kesehatan namun pada pelaksanaan program ini diketahui masih ada biaya out of pocket (OOP) yang dikeluarkan oleh masyarakat ${ }^{5}$. Kemampuan asuransi kesehatan dalam mengurangi pembayaran OOP, jenis OOP yang dapat meningkatkan pengeluaran kesehatan terutama di tingkat rumah tangga, dan strategi dalam alokasi finansial guna mengurangi OOP yang dikeluarkan rumah tangga penting untuk dianalisis. Untuk itu peneliti mencoba meneliti faktor yang mempengaruhi pemanfaatan asuransi kesehatan melalui variabel sosiodemografik.

\section{METODE}

Desain Studi. Data yang digunakan dalam penelitian ini adalah data sekunder. Data sekunder tersebut adalah Data
Indonesian Family Life Survey (IFLS) tahun 2015. IFLS merupakan survey berskala nasional yang dilaksanakan oleh RAN Corp, berupa survei rumah tangga panel yang telah dilakukan 5 putaran yaitu pada tahun 1993, 1997, 1998, 2000, dan 2007. Survei ini dilakukan di 13 provinsi dan survei panel dengan keberhasilan yang tinggi dalam menemukan kembali responden, mencapai $>90 \%$.

Etik Penelitian. Survei IFLS berada dibawah pengawasan IRB (Institutional Review Boards) di Amerika Serikat (di RAND) dan telah dikaji etik oleh Universitas Gadjah Mada untuk IFLS 3, IFLS 4 dan IFLS 5 di Indonesia.

Metode Analisis Data. Metode analisis yang digunakan dalam penelitian ini adalah analisis regresi Ordinary Least Square (OLS). Analisis regresi OLS merupakan metode untuk menganalisis hubungan antar variabel. Hubungan tersebut diekspresikan dalam bentuk persamaan yang menghubungkan variabel dependen dengan satu atau lebih variabel independen. Metode analisis yang digunakan adalah analisis regresi logit untuk mengetahui faktor-faktor yang pemanfaatan asuransi kesehatan di Indonesia.

\section{HASIL DAN BAHASAN}

Analisis deskriptif dilakukan untuk melihat distribusi frekuensi dari tiap variable penelitian dan mengetahui gambaran umum variabel yang digunakan dalam penelitian. Pada variabel dependen adalah pemanfaatan jaminan kesehatan, sedangkan variabel independen adalah umur, tingkat pendidikan responden, status dalam keluarga, status pekerjaan, status dalam keluarga, wilayah tempat tinggal. Hasil analisis univariat menggambarkan sebaran frekuensi dan persentase dari pemanfaatan jaminan kesehatan seperti pada tabel 1 .

Hasil analisis univariat dari pemanfaatan jaminan kesehtan menunjukkan bahwa jumlah pemilik jaminan kesehatan yang memanfaatkan jaminan kesehatannya yaitu sebanyak 60,08\% dari seluruh responden, sedangkan sisanya yaitu sebanyak 39,92\% pemilik jaminan kesehatan tidak menggunakan jaminannya pada saat mengakses layanan kesehatan.

Analisis bivariat menampilkan distribusi variansi dari variabel Y dependen tentang pemanfaatan jaminan kesehatan yang dimiliki dengan masing-masing variabel independen $(\mathrm{X})$.

Regresi ini dilakukan dengan mergress beberapa variabel bebas terhadap variabel independen secara bersama-sama. Dengan taraf signifikansi 1\%, 5\% dan 10\%

Tabel 1. Prevalensi Pemanfaatan Jaminan Kesehatan

\begin{tabular}{ccc}
\hline $\begin{array}{c}\text { Pemanfaatan } \\
\text { Jaminan Kesehatan }\end{array}$ & Frekuensi & Persen \\
\hline O & 745 & 60,08 \\
1 & 495 & 39,92 \\
\hline Total & 1240 & 100 \\
\hline
\end{tabular}


jika p-value 0,01;0,05; atau 0,1 maka variabel tersebut secara signifikan mempengaruhi variabel dependen.

Nilai signifikansi F-test diperoleh $0.000<0.05$ yang menyatakan bahwa semua variabel independen secara

Tabel 2 Karakteristik Subjek

\begin{tabular}{|c|c|c|}
\hline \multicolumn{2}{|c|}{ Variabel } & $\%$ \\
\hline \multicolumn{3}{|c|}{ Jenis Kelamin } \\
\hline- & Laki-laki & 59.95 \\
\hline- & Perempuan & 46.05 \\
\hline \multicolumn{3}{|c|}{ Status Pernikahan } \\
\hline- & Menikah & 19.76 \\
\hline- & belum/tidak menikah & 80,24 \\
\hline \multicolumn{3}{|c|}{ Status dalam Keluarga } \\
\hline- & Kepala Keluarga & 58.55 \\
\hline- & Anggota Keluarga & 41.45 \\
\hline \multicolumn{3}{|c|}{ Wilayah Tempat Tinggal } \\
\hline- & Rural & 26.85 \\
\hline- & Urban & 73.15 \\
\hline \multicolumn{3}{|c|}{ Status Pekerjaan } \\
\hline- & Tidak Bekerja & 15.4 \\
\hline- & Bekerja & 84.6 \\
\hline \multicolumn{3}{|l|}{ Umur } \\
\hline- & $<=25$ & 16.37 \\
\hline- & $26-35$ & 34.35 \\
\hline- & $36-45$ & 26.21 \\
\hline- & $46-55$ & 17.50 \\
\hline- & $>=56$ & 5.56 \\
\hline \multicolumn{3}{|c|}{ Pendidikan } \\
\hline- & Tinggi & 34.11 \\
\hline- & Rendah & 65.89 \\
\hline
\end{tabular}

bersama-sama berpengaruh signifikan terhadap variabel dependen. Persentase variabel dependen dapat dijelaskan oleh variabel independen dalam model OLS sebesar 2 persen $(0,02)$ berdasrakan nialai $\mathrm{R}$, sedangkan sisanya dijelaskan oleh faktor lain yang tidak diamati dalam penelitian ini.

Hasil analisis regresi logistik menunjukkan bahwa variabel yang berpengaruh secara signifikan dalam pemanfaatan jaminan kesehatan wilayah tempat tinggal, umur dan pendidikan. Responden dengan tingkat pendidikan yang lebih tinggi ( $p$-value $<0,05$ ) maka semakin besar probabilitas untuk memanfaatkan jaminan kesehatan yang dimiliki, artinya semakin tinggi tingkat pendidikan responden maka semakin besar kemungkinan untuk memanfaatkan jaminan kesehatan yang dimiliki.

Variabel kedua yang memiliki nilai signifikan yaitu wilayah tempat tinggal, dalam hal ini dpat diartikan bahwa responden yang tinggal di wilayah perkotaan memiliki kemungkinan untuk memanfaatkan jaminan kesehatan yang dimiliki lebih besar daripada responden yang tinggal di wilayah pedesaan. Variabel signifikan berikutnya adalah umur responden artinya semakin bertambah umur responden maka kemungkinan memanfaatkan jaminan kesehatan yang dimiliki juga semakin besar.

Odd ratio pada umur menunjukkan bahwa setiap kenaikan umur mempunyai peluang meningkatkan OR pemanfaatan jaminan kesehatan sebesar 0.016. Odd ratio pendidikan menunjukkan bahwa pada responden dengan pendidikan tinggi mempunyai peluang memanfaatkan jaminan kesehatan sebesar 0.17 lebih tinggi daripada responden yang berpendidikan rendah.

\begin{tabular}{|c|c|c|c|c|c|c|}
\hline Source & SS & df & MS & \multirow{2}{*}{\multicolumn{2}{|c|}{$\begin{array}{l}\text { Number of obs } \\
E(7,3007) \\
\text { Prob }>E\end{array}$}} & \multirow{2}{*}{$\begin{array}{r}3,015 \\
12.30 \\
0.0000\end{array}$} \\
\hline Mode1 & 20.1442465 & 7 & 2.87774951 & & & \\
\hline Residual & 703.455753 & 3,007 & .233939393 & \multirow{2}{*}{\multicolumn{2}{|c|}{$\begin{array}{l}\text { R-squared } \\
\text { Adj R-squared } \\
\text { Root MSE }\end{array}$}} & 0.0278 \\
\hline Total & 723.6 & 3,014 & .240079628 & & & .48367 \\
\hline askesuse & Coef. & Std. Err. & $t$ & $P>|t|$ & [95\& Conf. & Interval] \\
\hline $\operatorname{sex}$ & -.0034382 & .0253571 & -0.14 & 0.892 & -.0531571 & .0462808 \\
\hline kawin & -.0114766 & .0220614 & -0.52 & 0.603 & -.0547335 & .0317803 \\
\hline statklg & -.0098713 & .0265938 & -0.37 & 0.711 & -.0620151 & .0422726 \\
\hline wtt & .114547 & .019648 & 5.83 & 0.000 & .0760222 & .1530718 \\
\hline kerja & -.0275217 & .0189246 & -1.45 & 0.146 & -.0646282 & .0095848 \\
\hline age & .0038422 & .0006812 & 5.64 & 0.000 & .0025065 & .0051779 \\
\hline didik & .0395758 & .0189546 & 2.09 & 0.037 & .0024105 & .0767412 \\
\hline _cons & .1775096 & .0352839 & 5.03 & 0.000 & .1083266 & .2466926 \\
\hline
\end{tabular}




\begin{tabular}{|c|c|c|c|c|c|c|c|}
\hline \multicolumn{4}{|c|}{ Logistic regression } & \multirow{3}{*}{\multicolumn{2}{|c|}{$\begin{array}{l}\text { Number of obs } \\
\text { LR chi2 (7) } \\
\text { Prob > chi2 }\end{array}$}} & $=$ & 3,015 \\
\hline \multirow{3}{*}{\multicolumn{4}{|c|}{ Log likelihood $=-1986.5385$}} & & & $=$ & 85.18 \\
\hline & & & & & & $=$ & 0.0000 \\
\hline & & & & \multicolumn{2}{|c|}{ Pseudo R2 } & $=$ & 0.0210 \\
\hline askesuse & Coef. & Std. Err. & $z$ & $\mathrm{P}>|z|$ & {$[958$} & Conf. & Interval] \\
\hline $\operatorname{sex}$ & -.016661 & .1090319 & -0.15 & 0.879 & -.230 & 3596 & .1970375 \\
\hline kawin & -.0470546 & .0942937 & -0.50 & 0.618 & -.231 & 8668 & .1377577 \\
\hline statklg & -.0403568 & .1139547 & -0.35 & 0.723 & -.263 & 7038 & .1829903 \\
\hline wtt & .4995349 & .0860569 & 5.80 & 0.000 & .330 & 8664 & .6682033 \\
\hline kerja & -.1143398 & .0809817 & -1.41 & 0.158 & -.273 & 0609 & .0443814 \\
\hline age & .0161822 & .0029063 & 5.57 & 0.000 & .01 & 0486 & .0218785 \\
\hline didik & .1699777 & .0813152 & 2.09 & 0.037 & .010 & 6029 & .3293525 \\
\hline _cons & -1.370008 & .1544166 & -8.87 & 0.000 & -1.67 & 2659 & -1.067357 \\
\hline
\end{tabular}

Odd ratio untuk wilayah tempat tinggal menunjukkan bahwa responden yang bertempat tinggal di wilayah pedesaan mempunyai peluang memanfaatkan jaminan kesehatan yang dimilikinya sebesar setengah kali dibandingkan responden yang tinggal di wilayah perkotaan, artinya responden di wilayah perkotaan memiliki peluang 2 kali lebih besar dalam pemanfaatan jaminan kesehatan yang dimiliki.

Hasil perbandingan antara logit dan probit tidak menunjukkan adanya perbedaan dengan hasil logit sebelumnya, bahwa variabel yang signifikan adalah variabel wilayah tempat tinggal, pendidikan dan umur responden. Hasil penelitian ini menunjukkan variabel yang secara signifikan mempengaruhi pemanfaatan jaminan kesehatan adalah wilayah tempat tinggal, umur responden yaitu pada umur 15 sampai umur 81 tahun dan pendidikan

Umur responden diduga berpengaruh terhadap pemanfaatan jaminan kesehatan yang dimiliki. Hal ini bisa disebabkan karena diduga seiring dengan bertambahnya usia maka kesadaran akan pelayanan kesehatan dan pemenfaatan jaminan kesehatan semakin meningkat. Masyarakat Indonesia yang dapat mendaftarkan dirinya atau keluarganya menjadi peserta jaminan kesehaan adalah masyarakat dengan kategori umur dewasa.

Tingkat pendidikan erat kaitannya dengan tingkat pengertian tentang pemanfaatan jaminan kesehatan dan kesadaran terhadap kesehatan keluarganya. Tingkat pendidikan turut pula menentukan rendah tidaknya seseorang menyerap dan memakai pengetahuan khususnya tentang pemanfaatan jaminan kesehatan. Tingkat pendidikan pemilik jaminan kesehatan yang rendah mempengaruhi penerimaan informasi sehingga pengetahuan tentang pemanfaatan jaminan kesehatan menjadi terhambat atau terbatas.
Faktor wilayah tempat tinggal sangat erat kaitannya dengan akses untuk mencapai fasilitas kesehatan. Daereh perkoataan tentu memiliki akses yang jauh lebih mudah dijangkau daripada daerah pedesaan, selain itu jumlah fasilitas kesehatan di wilayah perkotaan biasanya juga lebih banyak. Hal ini menyebabkan pemanfaatan jaminan kesehatan oleh masyarakat perkotaan lebih maksil dibandingkan dengan masyarakat pedesaan. Semakin jauh dan sulit tempat seseorang ke tempat pelayanan, maka kecenderungan seseorang tersebut menggunakan pelayanan tersebut akan semakin rendah. Dengan jauhnya jarak, berarti lebih banyak lagi moda transportasi yang dibutuhkan untuk mencapai tempat pelayanan tersebut bila dibandingkan dengan tempat yang dekat dengan tempat pelayanan.

Variabel lain dalam penelitian ini yang tidak bermakna secara signifikan yaitu jenis kelamin, status pernikahan, status pekerjaan dan pendidikan. Variabel tersebut dalam teori perilaku termasuk dalam faktor predisposisi yaitu preferensi "pribadi" seseorang; dapat berupa karakteristik individu (umur, jenis kelamin, pekerjaan). Namun pada penelitian ini pendidikan tidak memilki pengaruh yang signifikan.

\section{SIMPULAN}

Penelitian ini memunjukkan prevalensi pemanfaatan jaminan kesehatan dari pemiliknya yaitu sebesar 39,9\% sedangkan 60,02\% pemilik jaminan kesehatan tidak memanfaatkan jaminan kesehatan yang dimiliki dan mengeluarkan biaya OOP. Ada hubungan antara umur, jenis kelamin, status pernikahan, status pekerjaan, status dalam keluarga, pendidikan dan wilayah tempat tinggal dengan dengan pemanfaatan jaminan kesehatan. 
Ketujuh variabel tersebut secara bersama-sama memiliki pengaruh pada besarnya pemanfaatan jaminan kesehatan, pengaruh, namun ada 3 variabel yang memiliki pengaruh paling signifikan yaitu umur, pendidikan dan wilayah tempat tinggal.

\section{UCAPAN TERIMA KASIH}

Kami berterima kasih kepada RAND Corp. sebagai penyedia data . Kami berterima kasih kepada bapak dan bapak Taufik Hidayat, SE, MSE pengajar mata kuliah Ekonometri Pelayanan Kesehatan Universitas Indonesia.

\begin{abstract}
ABSTRAK
Adanya program JKN yang diselenggarakan Badan Penyelenggara Jaminan Sosial Kesehatan diharapkan membantu masyarakat yang selama ini tidak mampu mengakses layanan atau fasilitas kesehatan. Adanya JKN juga diharapkan mampu menekan biaya OOP dari pengeluaran kesehatan namun pada pelaksanaan program ini diketahui masih ada biaya out of pocket yang dikeluarkan oleh masyarakat, artinya masih ada pemilik jamiann kesehatan yang tidak memanfaatkannya. Penelitian ini bertujuan untuk mengetahui prevalensi dan determinan yang mempengaruhi pemanfaatan jaminan kesehatan di Indonesia. Variabel yang diamati cukup bervariasi, yaitu umur, jenis kelamin, status pernikahan, status dalam keluarga, pendidikan, status pekerjaan, serta wilayah tempat tinggal. Data yang digunakan adalah Data IFLS tahun 2015 dan dianalisis dengan menggunakan regresi logistik/logit. Hasil penelitian menunjukkan bahwa prevalensi pemanfaatan jaminan kesehatan dari pemiliknya yaitu sebesar 39,9\% sedangkan 60,02\% pemilik jaminan kesehatan tidak memanfaatkan jaminan kesehatan yang dimiliki dan mengeluarkan biaya OoP. Variabel umur $(0,037)$, pendidikan $(0,000)$ dan wilayah tempat tinggal $(0,000)$ bermakna secara signifikan $(p$-value $<0,05)$ terhadap pemanfaatan jaminan kesehatan.
\end{abstract}

Kata kunci: pemanfaatan jaminan kesehatan, umur, pendidikan, wilayah tempat tinggal, logit 


\section{PUSTAKA}

1. Indonesia PR. Undang Undang RI No.40 Tahun 2004. 1999:1-16. http://www.komnasham.go.id/sites/default/ files/dokumen/UU NO 39 TAHUN 1999 HAM_0.pdf.

2. Sarwo YB. Model Pembiayaan Kesehatan Menuju Jaminan Semesta (Universal Coverage). Mmh. 2012;41(3):443-450.

3. Kemenkes RI. Summary for Policymakers. Clim Chang 2013 - Phys Sci Basis. 2013:1-30. doi:10.1017/ CB09781107415324.004

4. Peta Jalan JKN. Kementerian Sekretariat Negara Ri Sekretariat Wakil Presiden. 2015. http://www. tnp2k.go.id/images/uploads/downloads/Final_JKN_ Perjalanan Menuju Jaminan Kesehatan Nasional - Copy.pdf.

5. SuryowatiE. Pengeluaran Masyarakat untuk Kesehatan Masih Tinggi Meski Ada BPJS - Kompas. https:// nasional.kompas.com/read/2017/05/23/17413621/ pengeluaran.masyarakat.untuk.kesehatan.masih. tinggi.meski.ada.bpjs.

6. Peraturan Presiden Republik Indonesia Nomor 12 Tahun 2013 Tentang Jaminan Kesehatan.

7. Peraturan Pemerintah Republik Indonesia Nomor 101 Tahun 2012 Tentang Penerima Bantuan Iuran Jaminan Kesehatan.

8. Ribot, J.C. dan Peluso, N.L. 2003. A Theory of Access. Journal Of Rural Sociology, 68 (2) Rural Sociological Society.

9. Sangadji, E. M., dan Sopiah. 2013. Consumer Behavior: Perilaku Konsumen dan Strategi Pemasaran Jilid 2. Jakarta Erlangga.

10. Schlager, E. dan Ostrom, E. 1992. Property-Rights Regimes and Natural Resources : A Conceptual Analysis. Journal Of Land Economics. August 1992.

11. Thabrany, Hasbullah. 2014. Jaminan Kesehatan Nasional. PT RajaGrafindo Persada: Jakarta 